\title{
$\frac{100}{\mathrm{LuT}} \mathrm{RPES}$
}

\section{PRZECIWDZIAŁANIE BEZDOMNOŚCI ZWIERZĄT JAKO PROBLEM SPOŁECZNY}

\section{ODPOWIEDZIALNOŚĆ CZY PODPORZĄDKOWANIE?}

Zarządzanie populacjami zwierząt nie-ludzkich wpisuje się w antropocentryczną retorykę sankcjonująca dominację człowieka nad innymi gatunkami. Na metapoziomie analizy tego rodzaju działania pozostaja etycznie niejednoznaczne. Stosowane są trzy podstawowe metody zarządzania populacjami: zmniejszenie poziomu urodzeń (antykoncepcja i gonadotektomia), zwiększenie poziomu śmiertelności (trucie, stosowanie pułapek, eksterminacja przez zastrzelenie) oraz relokacja (przeniesienie w inne rejony - jak w przypadku zagrożonych wyginięciem likaonów: gdy osiedlają się blisko wiosek w Zimbabwe, sa wyłapywane i przenoszone w miejsca, w których nie stanowią zagrożenia dla ludzi, a jednocześnie nie są narażone na ataki kłusowników ${ }^{1}$; ustanowienie fizycznych barier - np. płoty). Tego rodzaju działania prowadzone sa szczególnie w stosunku do tych gatunków fauny, które zostały przez człowieka uznane za „szkodniki” ${ }^{2}$. Ale nie tylko. Dotyczą one także zwierząt dzikich oraz towarzyszących.

W XXI w. relacje ludzi i innych gatunków w ogromnej mierze sprowadzają się do szeroko rozumianej konsumpcji: zjadania produktów odzwierzęcych, wykorzystywania ich w przemyśle, otaczania się zwierzętami towarzy-

* Hanna Mamzer, Uniwersytet im. Adama Mickiewicza w Poznaniu, mamzer@amu.edu.pl, https://orcid.org/0000-0002-2251-7639

** Paweł Nowak, Uniwersytet im. Adama Mickiewicza w Poznaniu, pawel.nowak@amu.edu.pl, https://orcid.org/0000-0002-0200-0907

1 Painted Dog Conservation (2019).

2 Należy w tym miejscu przywołać bardzo ciekawe publikacje Gabrieli Jarzębowskiej, w których autorka argumentuje, że nawet w zakresie kontrolowania populacji szczurzych, traktowanych jako realne zagrożenie epizootyczne i epidemiologiczne $\mathrm{w}$ dużych aglomeracjach miejskich, stosuje się kastrację chemiczną polegającą na podawaniu szczurom środków antykoncepcyjnych, uznając ten sposób za skuteczniejszy i mniej ingerujący w środowisko naturalne niż trucizny stosowane w celu zabijania niepożądanych populacji gryzoni. 
szącymi, by dostarczały pozytywnych doznań. Kontakt ludzi ze zwierzętami dzikimi jest bardzo ograniczony i nacechowany lękami i obawami. Najbliżej człowieka żyją siłą rzeczy zwierzęta domowe, które ustawa z 21 sierpnia 1997 r. o ochronie zwierząt ${ }^{3}$ definiuje w art. 4 par. 17 jako: „tradycyjnie przebywające wraz z człowiekiem w jego domu lub innym odpowiednim pomieszczeniu, utrzymywane przez człowieka w charakterze jego towarzysza”. W praktyce są to psy i koty.

Dzisiaj w kulturze zachodniej prowadzone sa zaawansowane działania w kierunku takiego zarządzania populacjami zwierząt towarzyszacych, które będą minimalizowały problem bezdomności zwierząt, a które jednocześnie będą działaniami etycznymi. Masowe zabijanie zwierząt bezdomnych w krajach takich jak Rosja ${ }^{4}$ czy Rumunia ${ }^{5}$, szczególnie w przeddzień ważnych międzynarodowych wydarzeń, zasługuje na potępienie i jest jednoznacznie nieetyczne. Kierując się etycznymi przesłankami w postępowaniu wobec zwierząt, należy szukać takich rozwiązań, które będą miały charakter prewencyjny, a więc ograniczać rozród. Ingerencja w tę sferę nie jest jednak wolna od etycznych dylematów 6 .

Największą skuteczność w zakresie kontrolowania bezdomności zwierząt można osiagnąć przez synergiczne prowadzenie trzech rodzajów zabiegów: edukowania opiekunów, obligatoryjnego znakowania oraz programowej sterylizacji/ kastracji zwierząt. Najtrudniejszym z tych trzech rodzajów działań jest edukowanie opinii publicznej, choć właśnie to ono przyniosłoby najtrwalsze zmiany. Niestety na skutki tego procesu, podobnie jak na efekty wszystkich oddziaływań zmierzających do wywołania trwałych zmian postaw w ogóle, trzeba jednak długo czekać. Stąd promuje się dzisiaj trwałe znakowanie oraz gonadotektomię jako takie rozwiązania, które mają ograniczyć zjawisko bezdomności zwierząt towarzyszących. Jest to ważne przede wszystkim z punktu widzenia dobrostanu tych zwierząt, nie tylko rodzących się, ale i rodzicielskich, nierzadko bowiem tracą życie z powodu komplikacji okołoporodowych ${ }^{7}$.

Licznie prowadzone kampanie społeczne ${ }^{8}$ wskazują w bardzo sugestywny sposób, że los wielu nowo narodzonych zwierząt jest tragiczny i kończą one życie szybko, często w męczarniach. Te zaś które przeżywaja, jeśli nie trafią do adopcji, powiększają grono zwierząt bezdomnych, utrzymywanych w schroniskach, gdzie z braku socjalizacji i pogłębiających się dysfunkcji behawioralnych szanse na ich adopcje maleją z dnia na dzień. Wiele z tych zwierząt jest ostatecznie poddawanych eutanazji (Peter Singer wskazuje na ogromny

${ }^{3}$ Dz. U. 1997, Nr 111, poz. 724 (dalej jako: u.o.z.).

${ }^{4}$ Amos (2018).

${ }^{5}$ Powell, Dawis (2015).

${ }^{6}$ Wysocka-Andrusiewicz (2019).

${ }^{7}$ Nie tylko złych warunków bytowych, ale i infekcji oraz trudności w wydaniu na świat potomstwa, szczególnie w wyniku nieodpowiedzialnego dopuszczania do zapładniania małych suk przez duże samce. Może to dawać potomstwo nieproporcjonalnie duże w stosunku do rozmiarów kanału rodnego matki i utrudniać lub uniemożliwiać poród.

${ }^{8}$ Lopez Negrete Communications (2010). 
problem zbyt pochopnych eutanazji w krajach skandynawskich, gdzie uśmiercenie zwierzęcia jest powszechnie wykorzystywane jako metoda pozbycia się niechcianych osobników, także zwierząt w pełni zdrowych ${ }^{9}$ ).

Problem bezdomności w przypadku dwóch najważniejszych dla człowieka gatunków zwierząt towarzyszących, a więc psów i kotów, wygląda odmiennie dla każdego z nich. O ile bowiem w Polsce w zasadzie nie ma psów wolno bytujących (jak w innych krajach europejskich [np. we Włoszech] czy azjatyckich [np. Gruzji czy Armenii] ${ }^{10}$ ), o tyle właśnie wzrastająca wolno bytująca kocia populacja jest problemem nie tylko dla środowisk ludzkich (jako czynnik rozprzestrzeniania zoonoz, zanieczyszczeń odchodami itd.), lecz także dla ekosystemowej równowagi biologicznej i bioróżnorodności, szczególnie innych dziko żyjących gatunków (przede wszystkim ptaków). Inny proces udomowienia kotów oraz krótszy niż psów czas jego trwania doprowadził do stanu, w którym współcześnie koty są daleko bardziej niezależne od człowieka niż psy. Kontrolowanie populacji kociej jest więc znacznie większym wyzwaniem, tym bardziej że teoretycznie jedna niewysterylizowana kotka w ciagu 4 lat rozrodu (co jest tylko okresem przyjętym umownie, może on bowiem trwać dłużej) może dać 512 kociąt (zakładając średnią liczebność 3 miotów rocznie i 4 kociąt w każdym miocie, z których $50 \%$ to samice).

Nie tylko w Polsce liczba zwierząt przyjmowanych do schronisk dla bezdomnych zwierząt jest wyzwaniem. Wskazuje się na ten problem także w USA, gdzie niestety znaczna część zdrowych, nadających się do adopcji zwierząt jest corocznie poddawana eutanazji w schroniskach. Jak wskazuja Phillips, Hedge i Peralta9 ${ }^{9}$, corocznie uśmierca się w ten sposób 1,5 mln zwierząt, z czego $80 \%$ zdrowych. Aby zminimalizować ten stan rzeczy, należy dołożyć wszelkich starań, by zapobiegać ich rozmnażaniu się przez popularyzowanie gonadotektomii ${ }^{11}$.

Zgodnie z koncepcja ,jednego zdrowia” (one world, one health) ${ }^{12}$ dobrostan ludzi i innych gatunków wpływa na siebie. Idea jednego zdrowia proponuje, by analizować zdrowie świata ożywionego jako całości, na która składają się przynajmniej trzy integralne składniki: zdrowie ludzi, zdrowie zwierząt nie-ludzkich i zdrowie roślin. Zdrowie tych trzech grup organizmów żywych jest wzajemnie uwarunkowane siecią powiązań działających zwrotnie na pozostałe elementy. Koncepcję „jednego zdrowia” należy rozumieć więc jako holistyczne spojrzenie na cały świat ożywiony, który oczywiście osadzony jest w swoim geograficzno-przestrzennym kontekście. Takie myślenie odzwierciedla założenie o tym, że społeczeństwa ludzkie nie są oderwane od przyrodniczego świata, ale że nakładając się, płynnie przechodza jedne w drugie.

\footnotetext{
9 Singer (2018).

10 Phillips, Hedge, Peralta (2018): 401.

11 Plesińska, Włosowicz (2018): 139-151.

12 Destoumieux-Garzón et al. (2018).
} 


\section{PODSTAWA PRAWNA}

Zapobieganie bezdomności zwierząt jest w Polsce obowiązkiem nałożonym na gminy i wynikającym z ustawy o ochronie zwierząt, w której ustawodawca stwierdza, że: „Zapobieganie bezdomności zwierząt i zapewnienie opieki bezdomnym zwierzętom oraz ich wyłapywanie należy do zadań własnych gmin" (art. 11.1), i wskazuje szczegółowo, że obowiązek ten jest realizowany przez coroczne uchwalenie do dnia 31 marca programu opieki nad zwierzętami bezdomnymi oraz zapobiegania bezdomności zwierzat, a program ten obejmuje w szczególności:

1) zapewnienie bezdomnym zwierzętom miejsca w schronisku dla zwierząt;

2) opiekę nad wolno żyjącymi kotami, w tym ich dokarmianie;

3) odławianie bezdomnych zwierząt;

4) obligatoryjną sterylizację albo kastrację zwierząt w schroniskach dla zwierząt;

5) poszukiwanie właścicieli dla bezdomnych zwierząt;

6) usypianie ślepych miotów;

7) wskazanie gospodarstwa rolnego w celu zapewnienia miejsca dla zwierząt gospodarskich;

8) zapewnienie całodobowej opieki weterynaryjnej w przypadkach zdarzeń drogowych z udziałem zwierząt.

Program taki może obejmować plan znakowania zwierząt w gminie oraz plan sterylizacji lub kastracji zwierząt, przy pełnym poszanowaniu praw właścicieli zwierząt lub innych osób, pod których opieką zwierzęta pozosta$\mathrm{ja}^{13}$. Ustawodawca narzuca więc gminom pewien sposób działania, ale też oferuje katalog możliwości wprowadzenia innych sposobów postępowania. W praktyce jednak okazuje się, że wiele gmin nie wykorzystuje tych możliwości, realizując jedynie ustawowo wymuszane minimum aktywności: „Realnych zachęt do przeprowadzania zabiegów kastracji lub sterylizacji zwierząt domowych mających właścicieli nie wprowadziło siedem kontrolowanych gmin [na 11 kontrolowanych - H.M., P.N.] Mińsk Mazowiecki, Siemiatycze, Kłomnice, Suchedniów, Serokomla, Pisz oraz miasto Grajewo" ${ }^{14}$. Tego rodzaju zachowawczość w działaniach gmin jest zastanawiająca, szczególnie wobec danych wskazujących, że podejmowanie realnych aktywności na rzecz ograniczania bezdomności zwierząt skutkuje obniżeniem nakładów przeznaczanych na rozwiązywanie problemu: „Wprowadzenie w gminie Suchy Las znakowania i ewidencji zwierząt, $\mathrm{w}$ tym realnych zachęt do znakowania psów przez ich właścicieli i umieszczanie danych o zwierzętach w dostępnej dla wszystkich międzynarodowej elektronicznej bazy Safe Animal, przynio-

\footnotetext{
${ }^{13}$ Art. 11a u.o.z.

14 NIK (2016): 15-16.
} 
sło efekt w postaci zmniejszenia w latach 2012-2015 liczby psów odłowionych (ze 105 do 82), przekazanych do schroniska (ze 103 do 27) i wydatków na ich utrzymanie (ze 110 tys. zł do 43,8 tys. zł)" ${ }^{15}$.

\section{STAN FAKTYCZNY W ZAKRESIE BEZDOMNOŚCI ZWIERZĄT W POLSCE}

Gminy w Polsce zobowiązane sa do obligatoryjnej sterylizacji/ kastracji zwierząt trafiających do schronisk. Prócz tego mogą oferować mieszkańcom właścicielom zwierząt towarzyszących, programy sterylizacji/ kastracji psów i kotów. Mogą także realizować programy typu „złapać - wysterylizować - wypuścić", które są wykorzystywane do zarządzania wielkością populacji zwierząt wolno bytujących (w Polskich warunkach dotyczy to oczywiście kotów). W praktyce oznacza to wyasygnowanie z budżetu danego samorządu środków finansowych, o które moga ubiegać się mieszkańcy gminy w celu przeprowadzenia wspomnianych zabiegów na zwierzętach własnych (albo też kotach wolno bytujących). Do tego rodzaju „realnej zachęty” motywuje NIK, wskazując, że takie działania znacząco przyczyniają się do ograniczania bezdomności zwierząt w ogóle, gdyż znoszą ryzyko przypadkowego, niekontrolowanego rozrodu zwierząt. Wskazać przy tym należy, że w świetle ustawy o ochronie zwierząt nielegalne jest w Polsce rozmnażanie zwierząt poza hodowlami zrzeszonymi w profesjonalnych związkach i stowarzyszeniach.

Jak wskazuje raport $\mathrm{NIK}^{16}$, problem bezdomności zwierząt w Polsce narasta, mimo przeznaczania na jego rozwiązanie coraz większych środków: „Na koniec 2014 roku funkcjonowały w Polsce 184 schroniska dla zwierząt, tj. o 34 więcej niż w 2011 roku. W stosunku do 2011 roku wzrosła liczba zarówno przebywających w schroniskach psów (do 105,7 tys., tj. o 5,4\%), jak i kotów (do 24,1 tys., tj. o $17,8 \%$ ). Tylko nieznacznie wzrosła liczba i odsetek adoptowanych zwierząt: w 2014 roku adoptowano 59,3 tys. (56\%) psów przebywających w schroniskach".

Okazuje się więc, że działania prowadzone przez gminy są nieskuteczne, opieka bowiem nad zwierzętami bezdomnymi realizowana jest fasadowo przez zlecanie wyłapywania zwierząt oraz umieszczanie ich w schroniskach. Nie rozwiąuje to kłopotu, a jedynie usuwa go z pola widzenia. Zamykając wyłapane zwierzęta $\mathrm{w}$ schroniskach, gminy zyskują pozór kontrolowania sytuacji, w myśl zasady „czego nie widać, tego nie ma”. W sposób bardzo dosłowny ta zasada ma zastosowanie w omawianej sprawie, schroniska bowiem sa przez opinię publiczną traktowane jako instytucje uciążliwe i niepożądane. Są więc lokalizowane na obrzeżach miast, w oddaleniu od ludzkich siedzib

\footnotetext{
15 NIK (2016): 15-16.

${ }^{16}$ NIK (2016): 7.
} 
oraz oddzielone różnego rodzaju barierami architektonicznymi, które maja zmniejszyć uciążliwość sassiedzką schronisk - zarówno przez ukrycie aspektów wizualnych wywołujacych nieprzyjemne emocje u osób postronnych (psy/ koty umieszczone w kojcach/ klatkach; wokalizujące; wykazujące stereotypie itd.), jak i minimalizowanie wpływu bodźców dźwiękowych związanych ze szczekaniem psów zgromadzonych w dużej liczbie na małym terenie oraz wynikającymi z tego stanu rzeczy odorami.

Obowiązek zapobiegania bezdomności zwierząt wynikający z ustawy jest kosztogenny. W trosce o interes publiczny i wykazanie gospodarności w zakresie wydatkowania środków publicznych gminy powinny dążyć do ich minimalizowania przez zapobieganie pojawianiu się problemu. Na niewłaściwe wydatkowanie środków publicznych w tym zakresie wskazuje raport NIK z 2012 r., dotyczacy kontroli gmin w zakresie realizacji obowiązku opieki nad zwierzętami bezdomnymi: „Ponad 1/3 środków publicznych przeznaczonych na ochronę zwierząt wydatkowano z naruszeniem prawa albo niegospodarnie"15. Stosowanie rozwiązań rekomendowanych przez NIK nie tylko rozwiązałoby problem, ale też bezpośrednio chroniłoby przed zarzutami niegospodarności, a rekomendacje NIK z kontroli realizacji obowiązku gmin w zakresie zwalczania bezdomności jednoznacznie wskazują na konieczność identyfikacji zwierząt i zachęcenie właścicieli do ich kastracji/ sterylizacji ${ }^{17}$.

\section{EFEKTYWNOŚĆ PROWADZENIA PROGRAMÓW STERYLIZACJI I KASTRACJI}

Brakuje publikacji naukowych zmierzających do przeanalizowania realnego wpływu programów sterylizacji/ kastracji w Polsce na obniżenie bezdomności zwierząt, zjawisko to nie jest więc badane naukowo, a jedynie sprawozdawczo prezentowane w postaci zestawień statystycznych, w których na podstawie koincydencji wnioskuje się o korelacji, co jest błędem logicznym. Nie można bowiem udowodnić na podstawie tych zestawień, czy nie zadziałały inne czynniki zewnętrzne (zmienne zakłócające), które wpłynęły na obniżenie poziomu bezdomności zwierząt. Jednocześnie nie można także wykluczyć istnienia takiej korelacji. Doniesienia medialne z gmin wskazują: „Zalety podobnych akcji widać zwłaszcza na przykładzie gminy Dzierżoniów, gdzie przez 2 lata z udziałem Stowarzyszenia Inicjatyw Obywatelskich prowadzono akcję kastracji 3000 psów i kotów. W efekcie liczba przynoszonych szczeniąt do tamtejszego schroniska "Azyl" zmalała z kilkuset rocznie do zaledwie kilku, a liczba zwierząt z 270 zmniejszyła się do 90 osobników, o czym przeczytamy na stronie kastrujemybezdomnosc.pl. Podobny sukces odnotowano w gminie Myszków, która sama poradziła sobie z bezdomnością zwierząt. Miejski pro-

\footnotetext{
${ }^{17}$ NIK (2012): 8.
} 
gram kastracji i czipowania realizowany w latach 2012 do 2014 zaowocował spadkiem bezdomnych psów ze 164 do 81, zaś wydatki gminy na ten cel zmalały ze $164000 \mathrm{zl}$ do $81000 \mathrm{zl}{ }^{18}$.

W innym miejscu czytamy natomiast: „Najlepszym przykładem jest gmina Suchy Las, gdzie po czterech latach konsekwentnych działań osiagnięto zarówno znaczący spadek liczby odłowionych zwierząt (o 22\%), jak i zmniejszenie wydatków na opiekę nad nimi (aż o 60\%). Było to efektem zapewnienia dofinansowania kastracji lub sterylizacji zwierząt posiadajacych właścicieli oraz wprowadzenia czipowania wszystkich, a także rejestrowania ich w ogólnodostępnej internetowej bazie danych, dzięki czemu możliwe było występowanie do właścicieli o zwrot kosztów pobytu odłowionego zwierzęcia $\mathrm{w}$ schronisku i zapewnienia mu $\mathrm{w}$ tym czasie opieki weterynaryjnej. Kastrację lub sterylizację zwierząt mających właścicieli prowadziła też gmina Dobra. Innym przykładem dobrej praktyki było podjęcie przez Radę Miasta Łuków uchwały w sprawie zwolnień właścicieli z opłaty od posiadania psów poddanych sterylizacji i zaczipowanych oraz wpisanych do rejestru w urzędzie Miasta"19.

Jeśli informacje przedstawiane przez urzędy gmin jako sprawozdania z wykonanych zadań traktować jako twarde dane statystyczne - a nie ma podstaw, by tak nie robić - to należy uznać, że rzeczywiście istnieć mogą korelacje pomiędzy wprowadzeniem programów sterylizacji/ kastracji zwierząt a zmniejszeniem się ich liczebności w schroniskach, przy czym wskazać należy, że efekty takich działań są długofalowe, a także osiagane po dłuższym czasie.

\section{METODOLOGIA PRZEPROWADZONYCH BADAŃ}

W czerwcu 2019 r. do wszystkich gmin w Wielkopolsce zostały rozesłane drogą elektroniczną zapytania o dostęp do informacji publicznej z wnioskiem o udzielnie następujących informacji:

1. Czy w Państwa gminie jest realizowany program sterylizacji/ kastracji zwierząt właścicielskich? (Nie jest wymagany przez ustawę o ochronie zwierząt, ale jest zalecany).

2. Jeśli tak - od którego roku jest ten program prowadzony?

3. Jaki był budżet na ten program w latach: 2016, 2017, 2018 ?

4. Ile psów i ile kotów poddano zabiegom w latach: 2016, 2017, 2018 ?

Jedynie 19\% gmin w Wielkopolsce realizuje program sterylizacji/ kastracji zwierząt właścicielskich. Zdecydowana natomiast większość - aż $63 \%$ - niestety nie przewiduje w ramach budżetu gminnego finansowania zabiegów

\footnotetext{
18 Przybek (2017).

19 Skorupski (2017): 103.
} 
sterylizacji/ kastracji zwierząt, których właścicielami są mieszkańcy gminy. Zestawienie wyników dla powyższych danych prezentuje wykres 1 .

Rozpatrując datę wprowadzenia przez gminy programu kastracji/ sterylizacji zwierząt właścicielskich, można zauważyć (wykres 2), że pionierskie działania w tym zakresie podjęto w 2008 r., kiedy to pierwsze trzy gminy rozpoczęły finansowanie zabiegów. Wśród nich znalazła się również jedna z dziesięciu najbogatszych gmin w Polsce w 2008 r. - Suchy Las, z dochodem na jednego mieszkańca wynoszącym wówczas 6312,90 złํ. W latach 2009-2011 nastapiła natomiast całkowita stagnacja w podejmowaniu przez gminy inicjatyw w zakresie programów kastracji/ sterylizacji zwierząt właścicielskich, co może być podyktowane wpływem globalnego kryzysu gospodarczego z 2008 r. Właściwe rozpoczęcie procesu systematycznego uruchamiania tego typu programów nastapiło w 2012 r. Od tego czasu corocznie kolejne gminy rozpoczynały finansowanie zabiegów. Szczytowym zaś rokiem był 2017, kiedy to 8 gmin podjęło wskazane działania (wykres 2).

Budżet programów kastracji/ sterylizacji zwierząt właścicielskich w gminach w latach 2016-2018 (wykres 3) rósł wprost proporcjonalnie do liczby gmin prowadzących program:

1. W 2016 r. łącznie 24 gminy prowadziły program kastracji/ sterylizacji zwierząt właścicielskich, a całkowity budżet wyniósł 292525 zł.

2. W 2017 r. łaccznie 32 gminy prowadziły program kastracji/ sterylizacji zwierząt właścicielskich (wzrost o 33,7\% w stosunku do roku poprzedniego), a całkowity budżet wyniósł 390989 zł (wzrost o 33,3\% w stosunku do roku poprzedniego).

3. W 2018 r. łacznie 38 gmin prowadziło program kastracji/ sterylizacji zwierząt właścicielskich (wzrost o 18,0\% w stosunku do roku poprzedniego), a całkowity budżet wyniósł 461460 zł (wzrost o 18,8\% w stosunku do roku poprzedniego).

Liczbę zwierząt poddanych zabiegom kastracji/ sterylizacji w latach 20162017 prezentuje wykres 4 . Wynika z niego przede wszystkim fakt, że liczba psów i kotów, które wykastrowano/ wysterylizowano w 2017 r. wzrosła w stosunku do roku poprzedniego o 147\% (z 1193 do 2948). Budżet przeznaczony przez gminy na ten cel w analogicznym okresie zwiększył się jedynie o 33,3\%. Wniosek, jaki można odczytać z tej relacji, wskazuje na obniżenie kosztu pojedynczego zabiegu o 46\% - z 254,20 zł w 2016 do 132,63 zł w 2017 r. Niestety tendencja ta nie utrzymała się już w kolejnym roku: w 2018 poddano zabiegowi łącznie 2984 zwierząt, co w zestawieniu z budżetem przeznaczonym przez gminy na to działanie (461 $460 \mathrm{zł}$ ) ukazuje wzrost ceny usługi weterynaryjnej o $17 \% \mathrm{w}$ stosunku do roku poprzedniego.

${ }^{20}$ GUS (2020). 


\section{Wykres 1}

Gminy realizujące program sterylizacji/ kastracji zwierząt właścicielskich

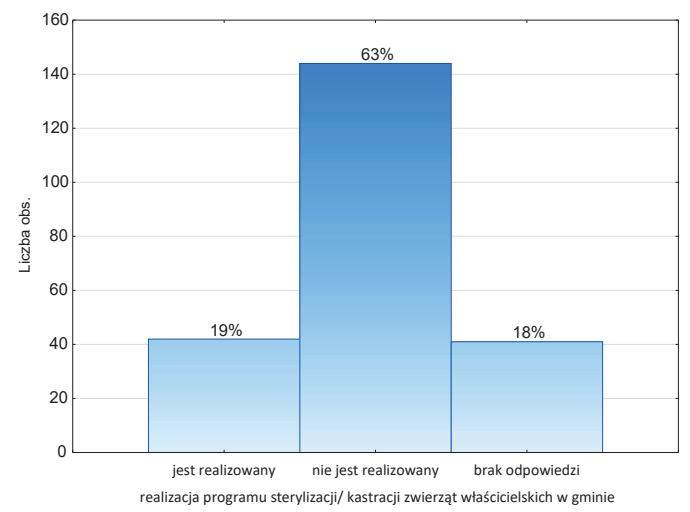

Źródło: opracowanie własne.

\section{Wykres 3}

Budżet programów kastracji/ sterylizacji zwierząt właścicielskich w gminach w latach 2016-2018

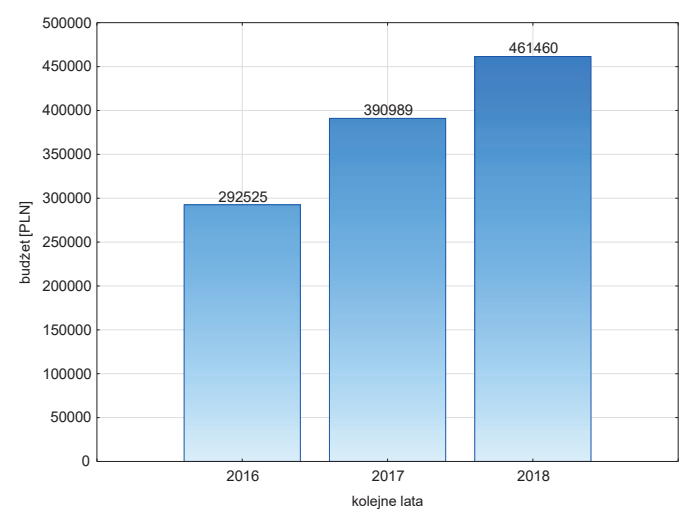

Źródło: opracowanie własne.

\section{Wykres 2}

Data wprowadzenia programu kastracji/ sterylizacji zwierząt właścicielskich $\mathrm{w}$ gminach

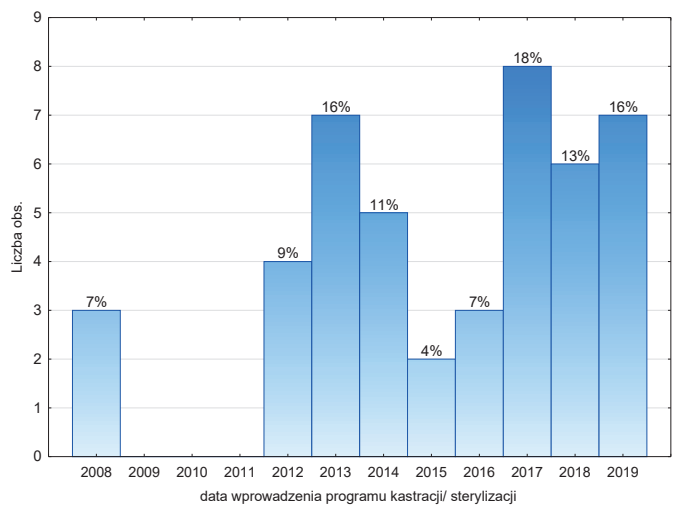

Źródło: opracowanie własne.

\section{Wykres 4}

Liczba zwierząt właścicielskich poddana zabiegom kastracji/ sterylizacji w ramach programów gminnych w latach 2016-2018

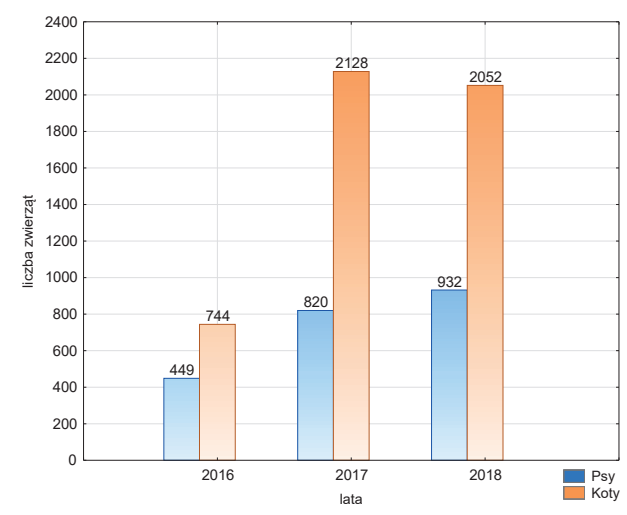

Źródło: opracowanie własne.

Kolejnym elementem przeprowadzonej analizy była weryfikacja stopnia korelacji pomiędzy budżetem gminy przeznaczonym na program kastracji/ sterylizacji zwierząt właścicielskich w latach 2016-2018 a liczbą przeprowadzonych zabiegów. Na podstawie wyliczonych wartości współczynnika korelacji Spearmana $(r)$ dla poszczególnych lat badanego okresu opracowano wykresy 5-7. 


\section{Wykres 5}

Korelacja rang Spearmana pomiędzy ilością zwierząt właścicielskich poddanych zabiegom kastracji/ sterylizacji w gminach w roku 2016 a budżetem programu
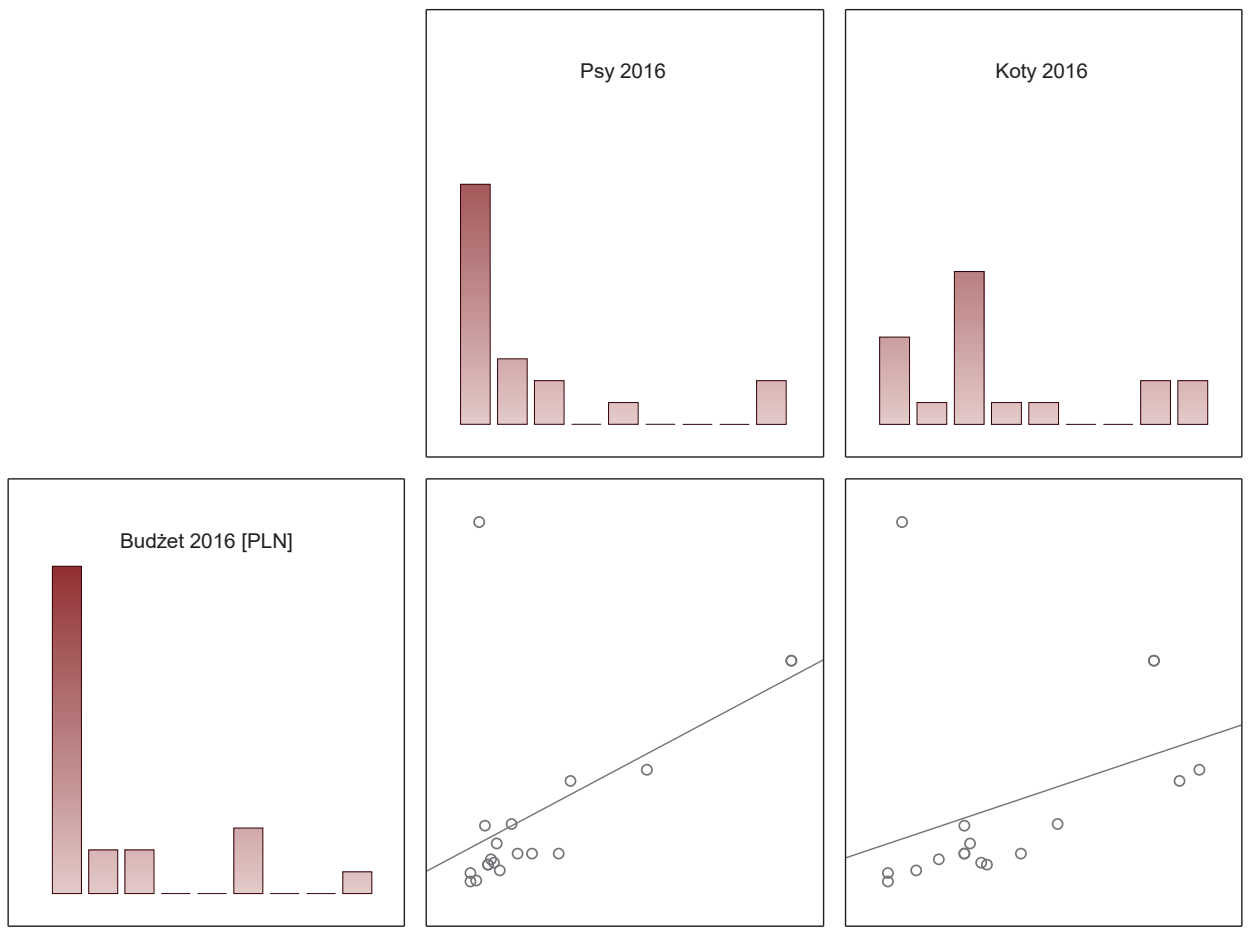

\begin{tabular}{|l|c|c|c|c|}
\hline & $n$ & $r_{\mathrm{s}}$ & $t_{(n-2)}$ & $p$ \\
\hline psy & 19 & 0,639366 & 3,428493 & 0,003204 \\
\hline koty & 17 & 0,594695 & 2,864902 & 0,011805 \\
\hline
\end{tabular}

Źródło: opracowanie własne. 


\section{Wykres 6}

Korelacja rang Spearmana pomiędzy ilością zwierząt właścicielskich poddanych zabiegom kastracji/ sterylizacji w gminach w roku 2017 a budżetem programu
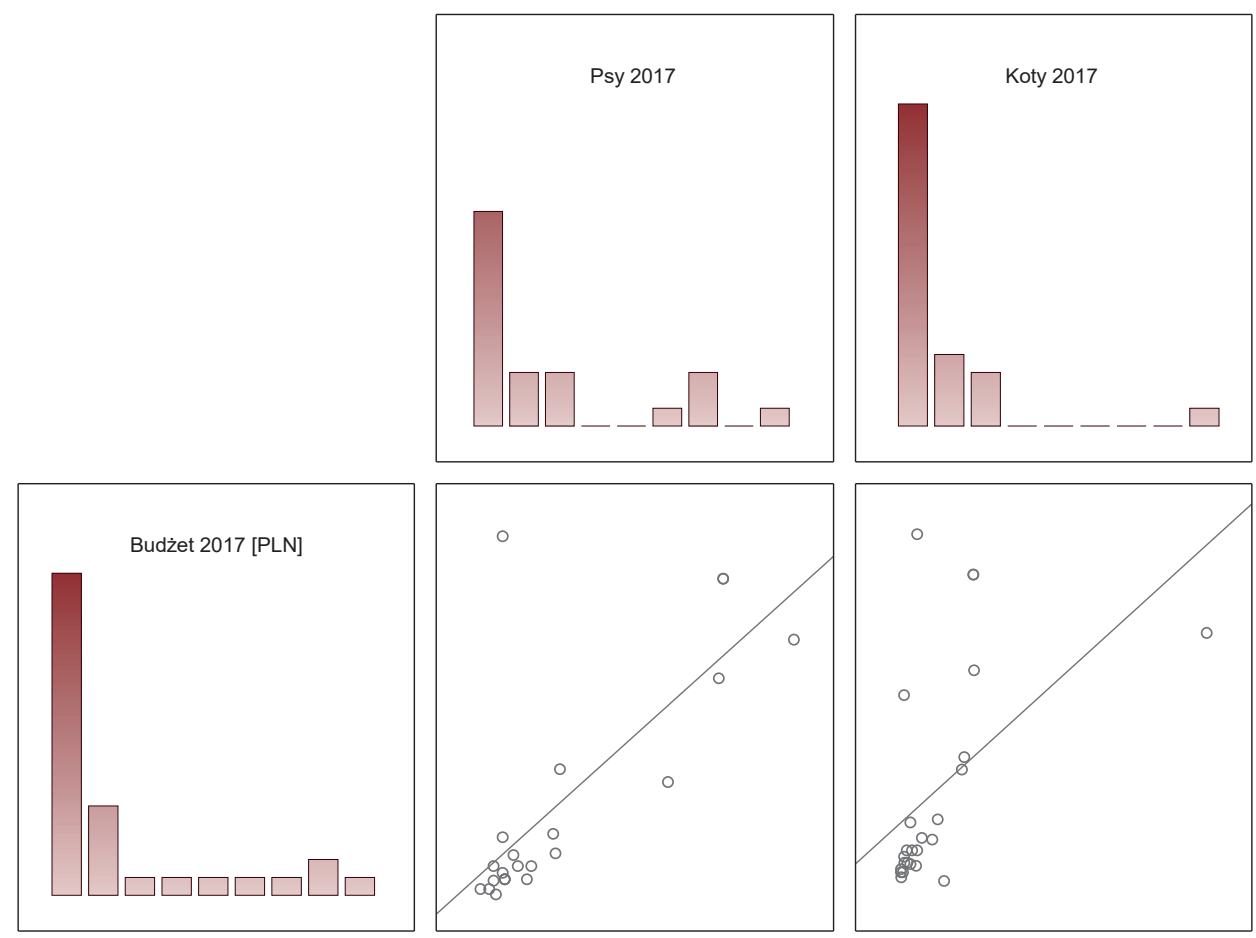

\begin{tabular}{|l|c|c|c|c|}
\hline & $\mathrm{n}$ & $\mathrm{r}_{\mathrm{s}}$ & $\mathrm{t}_{(\mathrm{n}-2)}$ & $\mathrm{p}$ \\
\hline psy & 23 & 0,733467 & 4,944890 & 0,000068 \\
\hline koty & 25 & 0,677140 & 4,413165 & 0,000201 \\
\hline
\end{tabular}

Źródło: opracowanie własne. 


\section{Wykres 7}

Korelacja rang Spearmana pomiędzy ilością zwierząt właścicielskich poddanych zabiegom kastracji/ sterylizacji w gminach w roku 2017 a budżetem programu

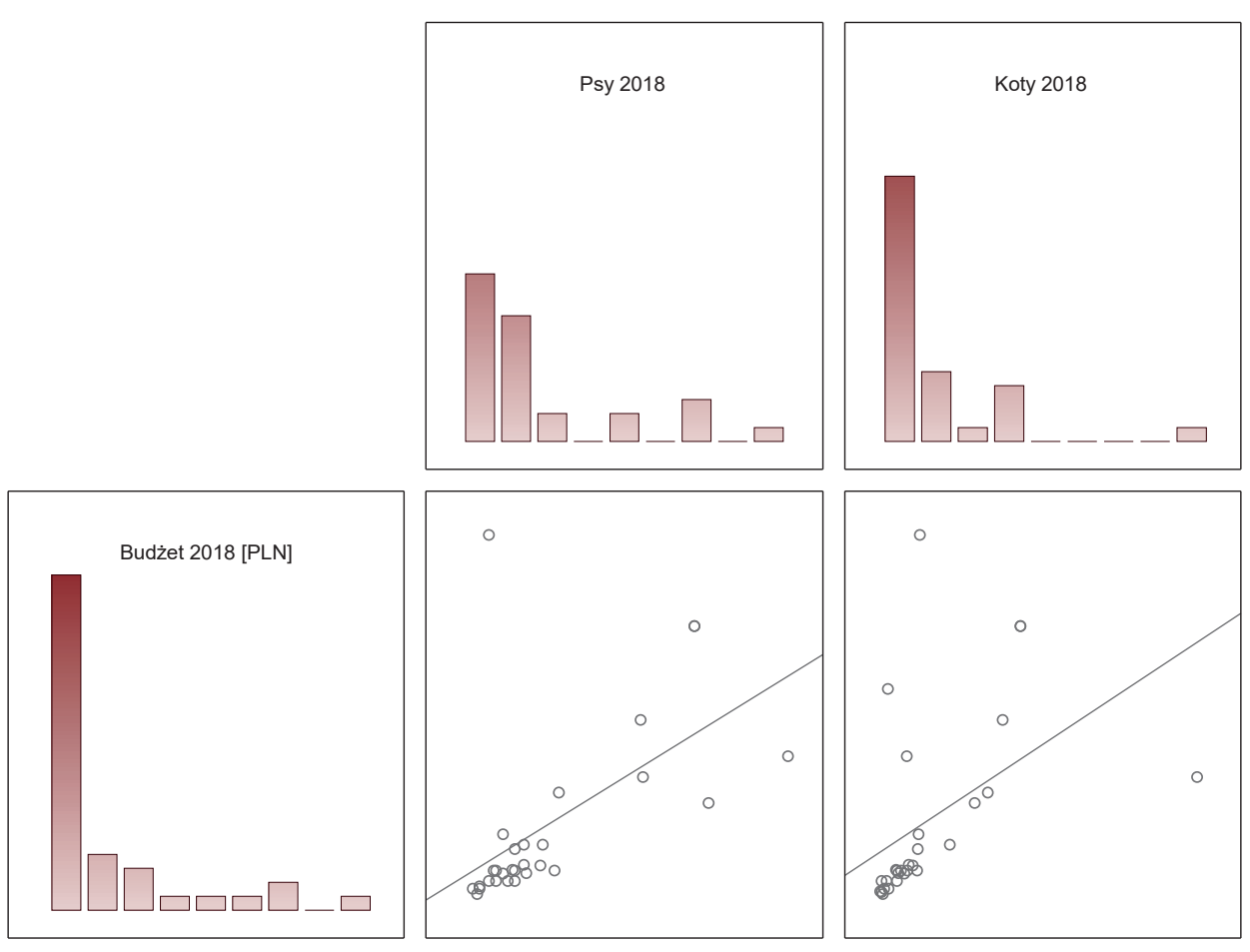

\begin{tabular}{|l|c|c|c|c|}
\hline & $n$ & $r_{\mathrm{s}}$ & $t_{(n-2)}$ & $p$ \\
\hline psy & 29 & 0,729196 & 5,537024 & 0,000007 \\
\hline koty & 29 & 0,813851 & 7,277730 & 0,000000 \\
\hline
\end{tabular}

Źródło: opracowanie własne.

W każdym roku, dla którego przeprowadzono badanie, wykazać można co najmniej wyraźną zależność między ilością przeprowadzony zabiegów sterylizacji/ kastracji zwierząt właścicielskich a budżetem przeznaczonym przez gminę na ten cel. Ponadto test $t$-studenta dla stopni swobody $n$-2, gdzie $n$ oznacza liczbę gmin realizujących program, w których przeprowadzono zabiegi weterynaryjne, oraz poziomy istotności wyliczone dla poszczególnych lat potwierdzają słuszność hipotezy: wraz ze wzrostem budżetu rośnie ilość zwierząt właścicielskich, które wykastrowano/ wysterylizowano w danym roku. Najwyższą wartość współczynnika korelacji uzyskano w roku 2018 dla kotów - $r_{\mathrm{s}}$ wyniósł 0,813851, co wskazuje na zależność bardzo dużą. 


\section{PRZYCZYNY NIECHECCI GMIN DO OFEROWANIA MIESZKAŃCOM MOŻLIWOŚCI STERYLIZACJI/ KASTRACJI ZWIERZĄT}

Na początku przedstawiamy argument najbardziej negatywny. Chociaż za zasadę naczelną należałoby przyjąć, że „Dobre schronisko, to puste schronisko", nie wszystkim jednak zależy na dobrostanie zwierząt. Schroniska gminne sa prowadzone ze względu na wymogi ustawowe, a nie z potrzeby serca kierującego się empatia. Ich funkcjonowanie jest finansowane na dwa sposoby: albo ryczałtem za określony czas, albo tzw. dniówką za utrzymanie konkretnego zwierzęcia przez konkretną liczbę dni. W przypadku stosowania ryczałtu w interesie schroniska jest jak najszybsze oddanie zwierząt do adopcji. W przypad$\mathrm{ku}$ stosowania dniówek korzystne finansowo jest utrzymywanie jak największej liczby zwierząt, przy czym ich utrzymanie powinno być jak najtańsze (stąd zdarzaja się sytuacje karmienia zwierząt bezdomnych odpadami poubojowymi złej jakości). Prowadzenie schronisk jako spółek komunalnych, jak wskazuje praktyka, jest polem znaczących nadużyć finansowych i etycznych. Działania tam realizowane są często nietransparentne, oparte na niedbale prowadzonej dokumentacji lub po prostu jej brak (nie wiadomo, ile jest zwierząt, jak sa leczone, jak podaje się leki, kto to robi). Znane są schroniska, w których celowo przetrzymane sa psy młode, których utrzymanie nie wymaga dużych nakładów, a „zaoszczędzone” środki mogą być zagospodarowane inaczej - w sposób legalny lub nie. Znane są także przykłady schronisk, które odmawiają wydawania do adopcji starych psów, utrudniają adopcje właśnie w celu utrzymania stałego stanu liczebnego, który gwarantuje określony budżet. Wobec faktu częstych powiązań personalnych w spółkach komunalnych i zarządach gmin działanie schronisk stanowi często przykrywkę dla wyprowadzania pieniędzy z budżetu gminy w pozornie legalny sposób. Powyższe praktyki zostały także jednoznacznie wskazane w raporcie NIK z $2016 r .{ }^{21}$ Tego rodzaju motywowane merkantylnie działania sa naganne moralnie i powinny być ścigane z urzędu nie tylko ze względu na realne straty finansowe generowane przez takie instytucje, ale także ze względu na wysoką szkodliwość społeczną takiego rodzaju działań pozbawionych wszelkiej empatii. W mojej ocenie jest to rodzaj działań całkowicie sprzecznych z u.o.z. i należy je traktować jako znęcanie się nad zwierzętami.

W drugiej kolejności niechęć niektórych gmin do podejmowania uchwał oferujących mieszkańcom programy sterylizacji/ kastracji wynika z pozornej oszczędności. Włodarze gmin są przekonani, że wydatkowanie środków na programy sterylizacji/ kastracji zwierząt, które mają opiekunów, jest albo zbędnym kosztem, albo wręcz „rozdawnictwem pieniędzy dla grup uprzywilejowanych". Jest to argument wynikający z braku szerokiego myślenia o dbałości o społeczeństwo. Samorządy gminne nie doceniają edukacyjnego elementu promowania programów sterylizacji/ kastracji zwierząt towarzyszacych jako istotnego czynnika modyfikującego postawy opiekunów. Jak wskazują nie-

${ }^{21}$ NIK (2016): 19. 
usystematyzowane obserwacje uczestniczące, fakt poddawania tym zabiegom zwierząt przez inne osoby jest czynnikiem motywującym do działania. Wzrastająca częstość wykonywania zabiegów działa na zasadzie ekspozycji bodźca: osoby nieprzekonane poddawane są klasycznemu procesowi habituacji na oddziaływanie bodźca, a więc niejako oswajają się z faktem, że gonadotektomie się wykonuje, że są pożądane i powszechnie stosowane. Jest to istotny czynnik w modyfikacji postaw ludzkich.

Po trzecie, jak słusznie wskazuje Gabriela Jarzębowska, analizując popularność różnych metod zabijania miejskich szczurów, demokracje zachodnie preferują krótkoterminowe sposoby kontroli wielkości populacji i dlatego trudno decydentom wskazać słuszność działań, których efekty będzie widać za 10-20 lat. Ma to szczególne znaczenie, wziąwszy pod uwagę, że cykle władzy trwają zazwyczaj 4-5 lat ${ }^{22}$. Taka krótkoterminowa perspektywa w pewnym sensie wymusza na decydentach podejmowanie działań, które - jeśli będą efektywne - będzie można uznać sukces osób sprawujących władzę. Samorządy z tego samego powodu, dla którego wolą truć szczurze populacje, zamiast zapobiegać ich rozmnażaniu antykoncepcja, wolą unikać oferowania programów sterylizacji/ kastracji zwierząt właścicielskich.

Modyfikowanie postaw ludzi zajmuje jednak dużo czasu i wymaga konsekwentnych programów edukacyjnych, które pozwoliłyby wygenerować zmianę. Jak wiadomo, modyfikowanie postaw należałoby rozpocząć we wczesnym wieku przed-/szkolnym, by po 20 latach uzyskiwać efektywne postawy, o spójnych komponentach poznawczym, emocjonalnym i behawioralnym. To rodzaj zadania, które jest długofalowe, a więc wymaga strategicznie pomyślanego, konsekwentnego planu działania, a przede wszystkim dalekowzrocznej perspektywy. Jest to trudne w realizacji. Dlatego w skutecznym ograniczaniu bezdomności zwierząt wykorzystywane są działania o charakterze interwencji weterynaryjnych, a mianowicie zabiegi sterylizacji i kastracji zwierząt. Mimo tego przeciwnicy realizowania programów kastracji/ sterylizacji zwierząt właścicielskich wysuwają następujące argumenty. (Zostały one zebrane podczas nieusystematyzowanych obserwacji uczestniczaccych):

1. „Gmina nie uchyla się od sterylizacji bezdomnych psów i kotów w schronisku".

Jak wskazaliśmy wcześniej, jest to obowiązek ustawowy wynikajacy z u.o.z., która nakazuje w art. 11a. 1 pkt 4 obligatoryjną sterylizację albo kastrację zwierząt w schroniskach. Wysuwanie tego argumentu ma odwrócić uwagę od dodatkowych możliwości działania gmin i skierować ją jedynie na ustawowo wymagane minimum.

2. „Gmina nie pobiera podatku od psa, więc już pomaga właścicielom zwierząt".

Ten argument pełni podobną funkcję - kieruje dyskusję na poboczne tory. Sterylizacje/ kastracje w sposób pośredni są pomocą dla opiekunów zwierząt.

22 Jarzębowska (2018): 11. 
Bezpośrednim celem tych programów jest jednak zupełnie co innego - mianowicie ograniczanie bezdomności zwierząt.

Gminy mają więc zapobiegać bezdomności zwierząt poprzez zachęcenie mieszkańców do sterylizacji/ kastracji zwierząt. Jak wskazaliśmy wcześniej, raport NIK z 2016 r. ocenia, że wyłapywanie zwierząt nie jest działaniem wystarczającym. Bardzo ważnym wsparciem minimalizowania bezdomności jest zapobieganie pojawianiu się zwierząt w schroniskach, a to można osiagnąć tylko poprzez identyfikację oraz kastracje/ sterylizacje oraz zachęcanie do wykonywania tych zabiegów u zwierząt majacych właścicieli²3.

Rezygnacja z pobierania podatków od właścicieli psów w zasadzie w praktyce wynika z dążenia samorządów do urealnienia sytuacji: jest podyktowana faktem, że ściagalność tych należności jest bardzo trudna, szczególnie wobec faktu, że w Polsce nie ma obowiązku znakowania zwierząt towarzyszacych. Rezygnacja z pobierania podatku nie ma więc żadnego związku z regulowaniem poziomu bezdomności zwierząt (szczególnie kotów - jako że właściciele tych zwierząt nigdy nie byli zobowiązani do płacenia podatków od zwierząt). Rezygnacja z pobierania podatków mogłaby mieć wpływ na poziom bezdomności, gdyby z wnoszenia opłat byli zwalniani właściciele psów oznakowanych i wysterylizowanych/wykastrowanych.

W Polsce brak badań i danych statystycznych, które wskazywałyby, czy koszty przeprowadzenia zabiegów sterylizacji/ kastracji są wyzwaniem dla opiekunów. W USA $17 \%$ kotów i psów mających opiekunów to zwierzęta niepoddane gonadotektomii. Większość tych zwierząt żyje w gospodarstwach domowych z rocznymi dochodami pomiędzy 20 a 35 tys. USD (co lokuje je w kategorii zarabiajacych mało - w czerwcu 2018 w USA mediana dochodów dla gospodarstw domowych wynosiła wg Sentier Research ok. 62 tys. USD). Te osoby często wskazuja, że koszty finansowe stanowią barierę w wykonaniu zabiegu u zwierzęcia ${ }^{24}$ (można przyjać uśredniony koszt zabiegu u psa na ok. 300 USD, kota podobnie). Zakładajacc, że oficjalne średnie zarobki w Polsce osiagają w tej chwili wysokość ok. 4800 PLN miesięcznie ${ }^{25}$, a koszt uśredniony zabiegu sterylizacji/ kastracji psa to ok. 300, kota - 200 PLN, to uznać można, że są to kwoty porównywalne (choć w przypadku danych statystycznych z USA mówimy o gospodarstwie domowym, a Polski - o indywidualnych zarobkach). Wskazywałoby to na fakt, że rzeczywiście część opiekunów zwierząt może mieć kłopot z finansowaniem zabiegów gonadotektomii, szczególnie jeśli w gospodarstwie domowym jest tych zwierząt kilka.

3. „Z bezpłatnych sterylizacji/ kastracji będą korzystać osoby spoza gminy”.

W gminie wiejskiej Tarnowo Podgórne wprowadzona została zasada opłacania sterylizacji/ kastracji zwierząt tylko tych osób, które legitymuja się „Kartą mieszkańca”, można też oprzeć identyfikację na miejscu zameldowania lub zamieszkania.

\footnotetext{
23 Skorupski (2017): 107.

24 Phillips, Hedge, Peralta (2018): 406.

25 PFRON (2019).
} 
4. „Do schroniska trafiają głównie psy dorosłe, a nie szczeniaki. Psy te pochodzą głównie od osób starszych i rodzin, które znudziły się swoim psem lub nie są w stanie dalej opiekować się zwierzęciem. A zatem ludzie, którzy oddaja psy do schroniska, i tak by je oddali bez względu na sterylizację, czyli sterylizacja psów nie wpłynie na liczbę psów zostawianych w schronisku”.

W świetle polskiego prawa schroniska dla bezdomnych zwierząt nie sa upoważnione do przyjmowania zwierząt w takich sytuacjach. Celem istnienia schronisk jest zapobieganie bezdomności zwierząt niemających opiekunów, a cała procedura wyłapania zwierzęcia przez uprawniony podmiot i umieszczenia go w schronisku jest także uregulowana prawnie. Zwierzęta, które się „znudziły”, nie powinny zatem trafiać do schronisk opłacanych ze środków publicznych, a ewentualnie do fundacji i stowarzyszeń. Taki stan rzeczy jest zapewne przyczyną porzucania zwierząt (szczególnie psów), podrzucania ich do schronisk, przywiazywania do drzew w lesie czy też zabijania, co jest wysoce naganne i wymaga uwagi ze strony ustawodawcy. Niemniej wskazać należy, że omawiany argument jest nietrafiony, ponieważ sterylizacja/ kastracja psów i kotów nie ma powodować, że zostaną one u właścicieli, ale że zwierzęta nie będą się rozmnażały, gdziekolwiek będą. Badania prowadzone w USA wskazuja, że psy niesterylizowane/ niekastrowane sa 2 do 3,5 razy bardziej narażone na porzucenie niż psy wykastrowane i wysterylizowane, a w przypadku niesterylizowanych i niewykastrowanych kotów są one 3,3 do 4,8 razy bardziej narażone na porzucenie niż osobniki kastrowane i sterylizowane ${ }^{26}$.

Niestety prawdą jest, że opiekunowie znudzeni swoimi zwierzętami nie dbają o ich dozór, szczególnie zaś na wsiach utrzymują na łańcuchach psy, co w przypadku suk w okresie cieczki jest gwarantem dochowania się psiego potomstwa.

5. „Dlaczego wszyscy mają się składać na sterylizację psów i kotów osób, które zdecydowały się na ich posiadanie? Jeśli kogoś stać na kupno psa za kilka tysięcy, to tym bardziej stać go na sterylizację".

Brak systematycznych badań statystycznych na temat tego, jakie osoby korzystają z oferowanych przez gminy programów bezpłatnej sterylizacji/ kastracji zwierząt, a także kto korzysta z podobnych możliwości oferowanych przez fundacje i stowarzyszenia. Nawet jeśli rzeczywiście korzystałyby z tych opcji osoby zamożne, to jednak płacąc podatki, także mają prawo korzystać z oferty opłacanej z budżetu gminy, niezależnie od statusu majątkowego. Socjologicznie zaś osoby zamożne często stanowią pewien rodzaj elit konsumpcyjnych (jak wskazywał Thorstein Veblen ${ }^{27}$ ), zatem mogłyby być traktowane jako liderzy opinii godni naśladowania. Ten mechanizm socjotechniczny, wzorowania się w działaniu na innych ludziach, jest często stosowany w różnego rodzaju praktykach z zakresu wywierania wpływu. Mógłby zatem zostać programowo i celowo wykorzystany także dla dobra omawianej sprawy.

\footnotetext{
${ }^{26}$ Phillips, Hedge, Peralta (2018): 406.

27 Veblen (2008).
} 
Wskazany w tym punkcie argument przeciw opłacaniu sterylizacji/ kastracji ze środków publicznych znów przekierowuje uwagę z jednego problemu (bezdomności zwierząt) na drugi (wspieranie finansowe osób, którym nie jest to potrzebne).

6. „Ze sterylizacji nie będą korzystały osoby, które zazwyczaj mieszkaja na wsi i to ich zwierzęta mają niechciane mioty. Ludzie tacy ignoruja prawa zwierzat i takie programy".

Pomijając oczywista, krzywdzącą stereotypizację widoczną w formułowaniu takiego argumentu, należy wskazać, że znowu, niestety, brak systematycznie gromadzonych danych statystycznych na ten temat. Na podstawie dostępu do informacji publicznej uzyskaliśmy wyrywkowe dane z małej wielkopolskiej miejsko-wiejskiej gminy Nekla, liczącej ok. 7 tys. mieszkańców. Jest to jedyna gmina w powiecie wrzesińskim, która dla swoich mieszkańców prowadzi program sterylizacji/ kastracji zwierząt. Dane statystyczne wskazuja, że z programu korzystają w połowie mieszkańcy wsi, a w połowie - miasta, co dokładnie odzwierciedla rozkład populacji gminy (ok. 3,5 tys. osób zamieszkuje miasto i ok. 3,5 tys. - wsie).

Osoby o niskich kompetencjach społecznych, niskiej inteligencji czy niskim poziomie edukacji, niepotrafiące sprawnie sobie radzić z różnego rodzaju wyzwaniami, pozostaja bezradne $\mathrm{w}$ sytuacji braku wsparcia $\mathrm{w}$ zakresie kontroli rozrodu zwierząt towarzyszących. Generuje to dla nich wyzwania, którym nadają znaczenie poboczne (wobec istotniejszych dla nich problemów) i których nie potrafią rozwiązać inaczej niż przez spontaniczne adopcje lub uśmiercanie ślepych miotów, które nie jest zlecane lekarzom weterynarii, a dokonywane „na własną rękę”. W świetle u.o.z. jest to oczywiście przestępstwo. Sądy oceniają je jednak często łagodnie, biorąc pod uwagę brak kapitału społeczno-kulturowego osób dopuszczających się tego rodzaju przestępstw. Nie zmniejsza to tragedii zwierząt. Z punktu widzenia świadomego obywatela wydaje się, że tego rodzaje sytuacje nie powinny mieć miejsca lub że zdarzają się marginalnie rzadko. Praktyka życia społecznego pokazuje jednak, że jest inaczej i dla osób, dla których obcowanie $\mathrm{z}$ formalnościami urzędniczymi jest wyzwaniem, pozyskanie wsparcia w zakresie rozwiązywania kłopotów jest szczególnie ważne. Oferując je, gminy rzeczywiście mogą oddziaływać na osoby, które wsparcia potrzebują.

\section{KONTROWERSJE I KONKLUZJE}

Poziom akceptacji społecznej dla działań takich jak sterylizacje/ kastracje zwierząt jest zróżnicowany, uwarunkowany poziomem wiedzy, kulturą oraz świadomością ekologiczna, a także dostępnością zasobów finansowych. Jak wskazuja Michał Pręgowski i Justyna Włodarczyk ${ }^{28}$, powszechna świadomość

${ }^{28}$ Pręowski, Włodarczyk (2016). 
na temat sensu przeprowadzania takich zabiegów jest bardzo ograniczona, a działania zmierzające do ograniczenia rozrodu zwierząt towarzyszących zostały w Polsce zintensyfikowane po roku 1989.

Jedna z form odpowiedzi na wzrastająca społeczną świadomość z zakresu konieczności ograniczania bezdomności zwierząt przez ich sterylizację/ kastrację stały się usługi oferowane przez „sterylkobusy” (,sterylobusy”) finansowane ze środków fundacji i stowarzyszeń. Zabiegi gonadotektomii zwierząt sa tu realizowane $\mathrm{w}$ specjalistycznie wyposażonych busach - mogą one dotrzeć do małych miejscowości, których mieszkańcom trudniej wyłapać zwierzęta i zawieźć je do stacjonarnego gabinety lekarza weterynarii.

Działania tego rodzaju spotkały się z krytyka ze strony indywidualnie wypowiadajacych się lekarzy weterynarii, jak i Krajowej Izby Weterynaryjnej ${ }^{29}$, chociaż opinie nie są w tym zakresie jednoznaczne i można znaleźć bardzo rzetelnie przygotowane i merytoryczne wypowiedzi wspierajace tego rodzaju działalnośćc ${ }^{30}$. W głosach krytycznych najważniejszy wydaje się argument braku weterynaryjnej opieki pozabiegowej dla pacjentów. Standard wyposażenia i higieny sterylkobusów można bowiem kontrolować, precyzyjnie określając wymogi higieniczne i sprzętowe, identyczne jak dla tradycyjnych gabinetów lekarzy weterynarii i ambulatoriów w schroniskach dla bezdomnych zwierząt. Wobec faktu, że niejednokrotnie stan higieniczno-sanitarny stacjonarnych ambulatoriów (np. w schroniskach) jest zatrważający, sterylkobusy mogłyby być realnym wsparciem w rozwiązywaniu problemu bezdomności zwierząt przez gonadotektomię.

Podczas gdy w Polsce dyskutujemy nadal nad tym, czy streylizować/ kastrować zwierzęta towarzyszace i jak to robić, a wiele osób nadal kieruje się w tym zakresie zabobonnymi przekonaniami o konieczności jednej ciąży dla normalnego zdrowia suki czy kotki, w USA dyskutuje się nad wadami i zaletami wczesnych sterylizacji/ kastracji zwierząt. Amerykańskie stowarzyszenie zrzeszajace lekarzy pracujacych w schroniskach dla zwierząt (Association of Shelter Veterinarians) wskazuje, że wiek 4 miesięcy u szczeniąt, a 5 u kociąt jest już wiekiem, w którym bez skutków negatywnych dla zdrowia zwierzęcia można dokonać gonadotektomii ${ }^{31}$. Temat jest ważny i pozostaje kontrowersyjny, gdyż tak wczesne zabiegi muszą jednak powodować u zwierząt skutki fizjologiczne, mogące mieć wpływ na ich dobrostan w późniejszym życiu ${ }^{32}$.

Bardzo ważne jest, by wykorzystywać synergiczny efekt wsparcia promowania gonadotektomii promowaniem trwałej identyfikacji zwierząt towarzyszacych. Akcentują to organizacje prozwierzęce ${ }^{33}$ i badania naukowe. Na przykład badania amerykańskie ${ }^{34}$ wskazuja, że ok. 15\% psów i kotów, przynajmniej raz w życiu się zagubiło; 93\% psów i 75\% kotów udało się odnaleźć i zwrócić opiekunom. Według tych badań 83\% kotów, które nie powróciły do

\footnotetext{
29 Krajowa Rada Lekarsko-Weterynaryjnej (2018): 74.

${ }^{30}$ Lisowski (2018); Phillips, Hedge, Peralta (2018): 405.

31 Spain, Scarlett, Houpt (2004).

32 Mendes-de-Almeida et al. (2011); Centonze, Levy (2002); Baś, Cywińska (2006).

33 Pollard-Post (2017).

34 Phillips, Hedge, Peralta (2018): 407.
} 
opiekunów, nie miało żadnych danych je identyfikujących; 56\% ze wszystkich zagubionych kotów także nie miało tych informacji. Podobnie w przypadku psów: 11\% zagubionych psów, które nigdy nie wróciły do domów, nie miało żadnych form identyfikacji ${ }^{34}$.

Prawa zwierząt, ich dobrostan oraz relacje ludzi i innych gatunków staja się coraz ważniejszym zjawiskiem społecznym, zwracającym uwagę zarówno szeroko rozumianej opinii publicznej, jak i przedstawicieli różnych dyscyplin nauki zajmujących się aktualnymi zagadnieniami społecznymi. Kontrole NIK przeprowadzone $\mathrm{w}$ schroniskach dla bezdomnych zwierząt jednoznacznie wskazuja, że stan schronisk jest zły. Są przegęszczone, zwierzęta nie mają należytej opieki weterynaryjnej, nie oferują zwierzętom możliwości zaspokajania potrzeb wynikających $\mathrm{z}$ ich naturalnego etogramu i nie socjalizuja zwierząt, a to prowadzi do zaburzeń behawioralnych utrudniających adopcję. Zwierzęta długotrwale przebywające $\mathrm{w}$ schronisku sa $\mathrm{w}$ zasadzie na nie skazane dożywotnio. Wzmiankowane kontrole NIK wskazuja, że niektóre ze schronisk stanowią swoiste obozy koncentracyjne ${ }^{35}$ i mają bardzo złą sławę, którą zawdzięczają nie tylko famie, ale nade wszystko wykreowanej tam rzeczywistości. Liczba zwierząt znajdujących się w schroniskach jest duża, a ich utrzymanie i opieka nad nimi stają się ważnym problemem społecznym. Większość schronisk dla bezdomnych zwierząt jest opłacana ze środków publicznych, a więc ze środków podatników. Jest to ogromny problem przede wszystkim w najważniejszym kontekście dobrostanu i jakości życia tych zwierząt, ale jest też ważne w kontekście funkcjonowania społeczności ludzkich, w tym finansów publicznych.

Amos, H. (2018). Is Russia killing stray dogs ahead of the World Cup? < https:/www.theguardian. com/ cities/2018/may/29/russia-stray-dogs-world-cup-cull-sochi-yekaterinburg> [dostęp: 24.04.2019].

Baś, M., Cywińska, A. (2006). Wczesna kastracja i sterylizacja psów i kotów. Życie Weterynaryjne 81(4): 246-250.

Centonze, L.A., Levy, J.K. (2002). Characteristics of free-roaming cats and their caretakers. Journal of the American Veterinary Medical Association 220(11): 1627-1633. doi:10.2460/ javma.2002.220.1627

Destoumieux-Garzón, D. et al. (2018). The one health concept: 10years old and a long road ahead. Frontiers in Veterinary Science 5. doi:10.3389/fvets.2018.00014

Jarzębowska, G. (2018). Follow the rat: from necropolitics to a theory of interspecies cohabitation. Journal for Critical Animal Studies 15(3): 4-25.

Krajowa Rada Lekarsko-Weterynaryjna (2018). Stanowisko Krajowej Rady Lekarsko-Weterynaryjnej z 19 grudnia 2017 r. w sprawie zabiegów operacyjnych wykonywanych masowo u psów i kotów poza siedzibami zakładów leczniczych dla zwierząt. Życie Weterynaryjne 93(2): 74.

Lisowski, A. (2018). Prywatna opinia na temat izbowej informacji o świadczeniu usług poza siedzibą zakładu leczniczego dla zwierząt. Życie Weterynaryjne 93(2): 84-86.

Lopez Negrete Communications (2010). Cesar Millan Spay and Neuter PSA - ENG. <https:// www.youtube.com/watch? v=RmmZ_XOHqCA> [dostęp: 24.04.2019].

Mendes-de-Almeida, F., Remy, G.L., Gershony, L.C. et al. (2011). Reduction of feral cat (Felis catus Linnaeus 1758) colony size following hysterectomy of adult female cats. Journal of Feline Medicine and Surgery: 436-440.

NIK (2012). Raport: Wykonywanie zadań gmin dotyczących ochrony zwierząt.

35 Pręowski, Włodarczyk (2016). 
NIK (2016). Raport „Zapobieganie bezdomności zwierząt”.

Painted Dog Conservation. (2019). PDC Newsletter First Quarter 2019. <https://mailchi. $\mathrm{mp} / 0 \mathrm{~cd} 5 \mathrm{~d} 56 \mathrm{c} 7 \mathrm{~b} 2 \mathrm{f} /$ pdc-newsletter-first-quarter-2019? $=$ =fd54257194> [dostęp: 30.01.2019].

PFRON (2019). Komunikat w sprawie przeciętnego wynagrodzenia. <http://www.e-pfron.pl/ index.php/komunikaty/ 89-przecietne -wynagrodzenie-1\#> [dostęp: 24.04.2019].

Phillips, S.C., Hedge, Z., Peralta, J.M. (2018). The role of private practitioners in reducing numbers of homeless dogs and cats and shelter euthanasia rates. Journal of the American Veterinary Medical Association 253(4): 404-408. doi:10.2460/javma.253.4.404

Plesińska, O., Włosowicz, M. (2018). Kto pocieszy kaukaskie psy? Non-fiction. Nieregularnik reporterski. Zwierzę 4: 139-151.

Pollard-Post, W. (2017). 'Fixing' Animal Homelessness the Right Way. <https://www.peta.org/ blog/ fixing-animal- homelessness-right-way/> [dostęp: 24.04.2019].

Powell, M. (2015). Davis, M., End your stray dog cull, UK tells Romania: diplomats step up pressure after 300,000 animals killed in crackdown. <https://www.dailymail.co.uk/news/article-3132979/ End-stray-dog-cull-UK-tells-Romania-Diplomats-pressure-300-000- animals-killed-crack-down. html> [dostęp: 30.01.2019].

Pręgowski, M.P., Włodarczyk, J. (2016). Researching the human-canine relationship in democratic Poland, [w:] M.P. Pręgowski, J. Włodarczyk (eds.), Free Market Dogs: The Human-Canine Bond in Post-Communist Poland. West Lafayette. West Lafayette: 1-35.

Przybek, A. (2017). Wiosenna akcja sterylizacji i kastracji zwierząt. <https://wpolityce.pl/blogi /398091-wiosenna-akcja-sterylizacji-i-kastracji-zwierzat> [dostęp: 24.04.2019].

Singer, P. (2018). Wyzwolenie zwierząt. Warszawa.

Skorupski, M. (2017). Zapobieganie bezdomności zwierząt. Ustalenia pokontrolne NIK, [w:] Kontrola Państwowa 2017/1. Warszawa.

Spain, C.V., Scarlett, J.M., Houpt, K.A. (2004). Long-term risks and benefits of early-age gonadectomy in dogs. Journal of the American Veterinary Medical Association 224(3): 380-387. doi:10.2460/javma.2004.224.380

Veblen, T. (2008). Teoria klasy próżniaczej. Tłum. J. Frentzel-Zagórska. Warszawa.

Wysocka-Andrusiewicz, J. (2019). O etycznym wymiarze ingerowania w seksualność pozaludzkich podopiecznych, [w:] H. Mamzer, A. Żok (red.), Bezpieczne czy zniewolone? Szkice o zwierzętach. Bydgoszcz: 249-277.

\section{TACKLING ANIMAL HOMELESSNESS AS A SOCIAL PROBLEM}

\section{Sum mary}

In terms of the welfare of both human and animal populations, in Western countries animal homelessness is a serious social challenge. Increasing emphasis is placed on controlling the size of the population of animals, particularly stray and feral ones. Three methods of reducing homelessness are most often indicated: education of animal owners, spaying/ neutering animals, and their permanent identification. In Poland the prevention of animal homelessness is a responsibility of the local municipalities. Although legislation allows municipalities to promote spaying/neutering animals that have owners, there are not many municipalities which decide to dedicate a budget for such activities. This is evaluated negatively by the highest Polish authorities and controlling institutions. In this text we present empirical research on introducing programs that encourage the owners of animals to conduct spaying/castrating procedures. We also identify reasons why municipalities are not willing to designate resources for this purpose.

Keywords: spaying; neutering; animal homelessness 